\title{
ANALISIS FLUIDA DAN PEMANFAATAN MATA AIR PANAS DAERAH SULILI KABUPATEN PINRANG PROVINSI SULAWESI-SELATAN
}

\author{
Emi Prasetyawati Umarr ${ }^{1}$, Alfian Nawir ${ }^{1}$, Jamal Rauf Husainn', Khadijah Rezkiani Tamar' ${ }^{1}$, Maria $^{3}$, \\ Jamaluddin $^{4}$, Muhamad Hardin Wakila ${ }^{1}$ \\ ${ }^{1}$ Jurusan Teknik Pertambangan, Fakultas Teknologi Industri, Universitas Muslim Indonesia \\ ${ }^{2}$ Departemen Teknik Geologi, Fakultas Teknik, Universitas Hasanuddin \\ ${ }^{3}$ Departemen Geofisika, Fakultas Matematika dan Ilmu Pengetahuan Alam, Universitas Hasanuddin \\ ${ }^{4}$ Program Studi Teknik Geologi, Sekolah Tinggi Teknologi Migas Balikpapan \\ *e-mail : emiprasetyawati.umar@umi.ac.id
}

\begin{abstract}
Abstrak. Daerah penelitian menunjukkan manifestasi panas bumi berupa mata air panas, analisis fluida mata air panas sangat penting dilakukan guna pemanfaatan yang lebih lanjut. Penelitian ini bertujuan untuk menganalisis sifat fisik dari mata air panas, kondisi fluida mata air panas dan mengetahui manfaat dari mata air panas daerah penelitian. Metode yang digunakan adalah analisis sifat fisik yang berupa nilai $\mathrm{pH}$, bau, rasa, temperatur, warna, $\mathrm{H}_{2} \mathrm{~S}$ sebagai Sulfida, TDS (Total Dissolved Solid) dan DHL (Daya Hantar Listrik). Hasil penelitian menunjukkan karakteristik mata air panas berwarna bening dengan hasil analisis laboratorium antara 4-23 TCU, berbau sulfur, rasa payau, suhu permukaan $45^{\circ} \mathrm{C}-57^{\circ} \mathrm{C}$, pH relatif netralbasa $(7,8-7,9)$, TDS 1,85-2,13 g/L menunjukkan mata air panas tergolong air payau dan klasifikasi air sadah non-karbonat, kekeruhan 0,95-6,04 NTU dan DHL yaitu 4,23-4,52 ms/cm. Nilai pH rata-rata dari mata air panas yaitu memiliki pH netral-basa dengan penciri mata air panas bersuhu rendah yang didominasi oleh air. Manfaat dari mata air panas pada daerah penelitian yaitu dalam bidang pariwisata sebagai tempat pemandian air panas, bidang kesehatan dan sebagai pusat studi terpadu.
\end{abstract}

Kata Kunci: analisis fisik fluida; fluida panasbumi; karakteristik fluida; mata air panas.

\begin{abstract}
The research area shows that geothermal manifestations are in the form of hot springs, and analysis of the hot water springs fluid is very important for more utilization. The aim of this study is to analyze the physical property of the hot water springs, hot spring fluid conditions, to find out the benefit of the hot water springs in the research areas. The method used is the analysis of physical properties of value of $\mathrm{pH}$, smell, taste, temperature, colour, $\mathrm{H}_{2} \mathrm{~S}$ as sulfide, TDS (Total Dissolved Solid) and DHL (Electrical Conductivity). The results showed that the characteristic of the hot water springs are shows the colored water of Sulili nodes with the results from laboratory analysis get 4-23 TCU, sulfur-smelling, taste brackish, surface temperature of $45^{\circ} \mathrm{C}-57^{\circ} \mathrm{C}$, $\mathrm{pH}$ relatively neutral-alkaline (7.8-7.9), 1.85-2.13g/L TDS shows springs the heat belongs to brackish water and non karbonat hardness water, the turbidity of 0.956.04 NTU and DHL i.e. $4.23-4.52 \mathrm{mS} / \mathrm{cm}$. The average $\mathrm{pH}$ value of hot springs is that it has a neutralalkaline $\mathrm{pH}$, identifier i.e. hot spring low temperature water which is dominated by water. The benefits of hot springs the area of research in the field of tourism as a place of hot water bath, health and as a field studies centre.
\end{abstract}

Keywords: fluid physical analysis; geothermal fluid; fluid characteristics; hot water springs.

\section{PENDAHULUAN}

Panas bumi adalah sumber daya alam berupa air panas atau uap yang terbentuk di dalam reservoir bumi melalui pemanasan air bawah permukaan oleh batuan panas. Sistem panas bumi merupakan salah satu sistem yang terjadi dalam proses geologi yang berjalan dalam orde ratusan bahkan jutaan tahun (Winarsih, 2014). Dewasa ini, panas bumi membawa manfaat bagi manusia baik dimanfaatkan secara tidak langsung maupun langsung dengan menjadikan manifestasi panas bumi sebagai tempat pariwisata, pertanian, perikanan, perkebunan dan peternakan.

Sistem panas bumi merupakan suatu daur hidrologi air (air tanah dan hujan) yang dalam perjalanannya berhubungan dengan sumber panas (heat source) bertemperatur tinggi sehingga terbentuk air panas yang dapat terperangkap dalam batuan dengan permeabilitas tinggi. Uap air dan air panas tersebut akan muncul ke permukaan melalui struktur-struktur seperti sesar atau rekahan (Umar dan Jamaluddin, 2018). Keberadaan manifestasi 
panas bumi di permukaan, diperkirakan terjadi karena adanya perambatan panas dari bawah permukaan atau karena adanya rekahan-rekahan yang memungkinkan fluida panas bumi mengalir ke permukaan (Tutu dkk., 2015).

Kemunculan mata air panas di Daerah Sulili dipengaruhi oleh adanya struktur geologi berupa kekar dengan tipe kekar sistematik (Umar dkk., 2020). Kekar-kekar ini merupakan media keluarnya mata air panas di permukaan. Berdasarkan hasil analisis terhadap data lapangan serta kaitannya dengan tektonik regional maka sesar yang bekerja pada Daerah Sulili berupa sesar geser (Umar dkk., 2020). Pengaruh geologi terhadap munculnya mata air panas ditandai dengan adanya struktur yang berupa sesar aktif dan kekar yang berkembang pada daerah tersebut.
Daerah Sulili menunjukkan karakterisitik panas bumi berupa manifestasi mata air panas. Penelitian ini dilakukan untuk menganalisis sifat fisik mata air panas yang meliputi bau, rasa, warna, temperatur, $\mathrm{pH}$, kekeruhan, $\mathrm{H}_{2} \mathrm{~S}$ sebagai Sulfida, TDS (Total Dissolved Solid) dan DHL (Daya Hantar Listrik) dalam rangka memberikan rujukan dalam pemanfaatan potensi energi panasbumi yang ada di daerah tersebut. Oleh karena itu, dilakukan penelitian tentang "Analisis Fluida dan Pemanfaatan Mata Air Panas Daerah Sulili Kabupaten Pinrang Provinsi Sulawesi-Selatan".

\section{METODOLOGI}

Lokasi penelitian terletak di Daerah Sulili Kecamatan Paleteang Kabupaten Pinrang, Provinsi Sulawesi Selatan. Secara geografis daerah penelitian

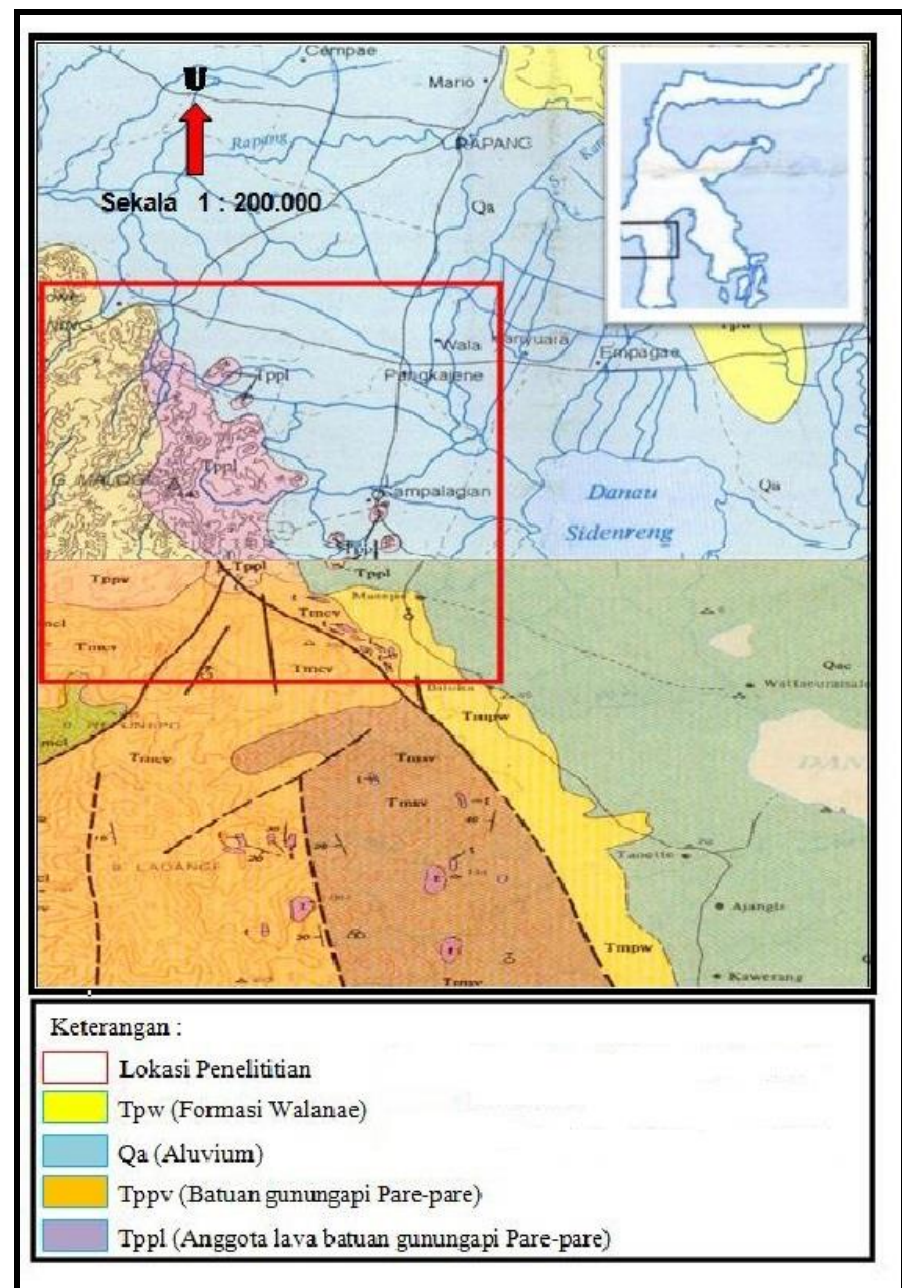

Gambar 1. Peta Tunjuk Lokasi Penelitian (Sumber: Bakosurtanal) 
dibatasi oleh daerah: Patampanua di bagian utara; Kabupaten Sidrap di sebelah timur; Kecamatan Wattang Sawitto di sebelah selatan. Luas daerah penelitian secara datar adalah $8 \mathrm{~km} \times 6 \mathrm{~km}$ atau 64 $\mathrm{km}^{2}$. Daerah ini terpetakan dalam Peta Geologi Indonesia skala 1: 200.000 pada lembar Pinrang, yang diterbitkan oleh Badan Kordinasi Survei dan Pemetaan Nasional (Bakosurtanal). Daerah penelitian terletak pada bagian tengah dari lembar Pinrang dan berjarak sekitar $182 \mathrm{~km}$ dari Kota Makassar. Lokasi penelitian dapat dicapai dengan menggunakan mobil atau bus yang ditempuh sekitar 4 jam (Gambar 1).

Metode yang digunakan adalah analisis sifat fisik dan kimia berupa nilai $\mathrm{pH}$, bau, rasa, temperatur, kekeruhan, $\mathrm{H}_{2} \mathrm{~S}$ sebagai Sulfida, TDS (Total Dissolved Solid) dan DHL (Daya Hantar Listrik).

Pengambilan data merupakan tahap kegiatan pengambilan seluruh data lapangan yang dibutuhkan. Data-data tersebut menunjang proses analisis. Data yang digunakan di antaranya adalah data primer berupa data nilai $\mathrm{pH}$, bau, rasa, warna, temperatur, kekeruhan dan dokumentasi kegiatan penelitian. Terdapat pula data hasil analisis laboratorium dari sampel yang diambil di tiga lokasi stasiun pengambilan data (ST-1, ST-2 dan ST-3) berupa $\mathrm{pH}$, warna, kekeruhan, $\mathrm{H}_{2} \mathrm{~S}$ sebagai Sulfida, TDS (Total Dissolved Solid) dan DHL (Daya Hantar Listrik) yang diuji di Laboratorium Oseanografi Kimia di Fakultas Ilmu Kelautan dan Perikanan Universitas Hasanuddin Makassar. Selain itu, digunakan juga data sekunder untuk mendukung proses analisis data berupa data peta lokasi penelitian, peta zonasi suhu daerah penelitian serta literatur yang berhubungan dengan judul penelitian.

Hasil pengolahan keseluruhan data kemudian diinterpretasi lebih lanjut guna menyimpulkan penelitian yang dilakukan untuk mengetahui sifat fisik dari mata air panas tersebut, kondisi fluida panas bumi dan mengetahui manfaat dari mata air panas daerah penelitian.

\section{HASIL DAN PEMBAHASAN}

\section{Sifat Fisik Mata Air Panas Daerah Penelitian}

Kegiatan pengamatan, pengukuran dan pengambilan data dilakukan pada tiga lokasi titik stasiun pada Daerah Sulili Kabupaten Pinrang Provinsi Sulawesi Selatan. Ketiga titik tersebut sebagai berikut:

Mata air panas Stasiun 1 (ST-1)

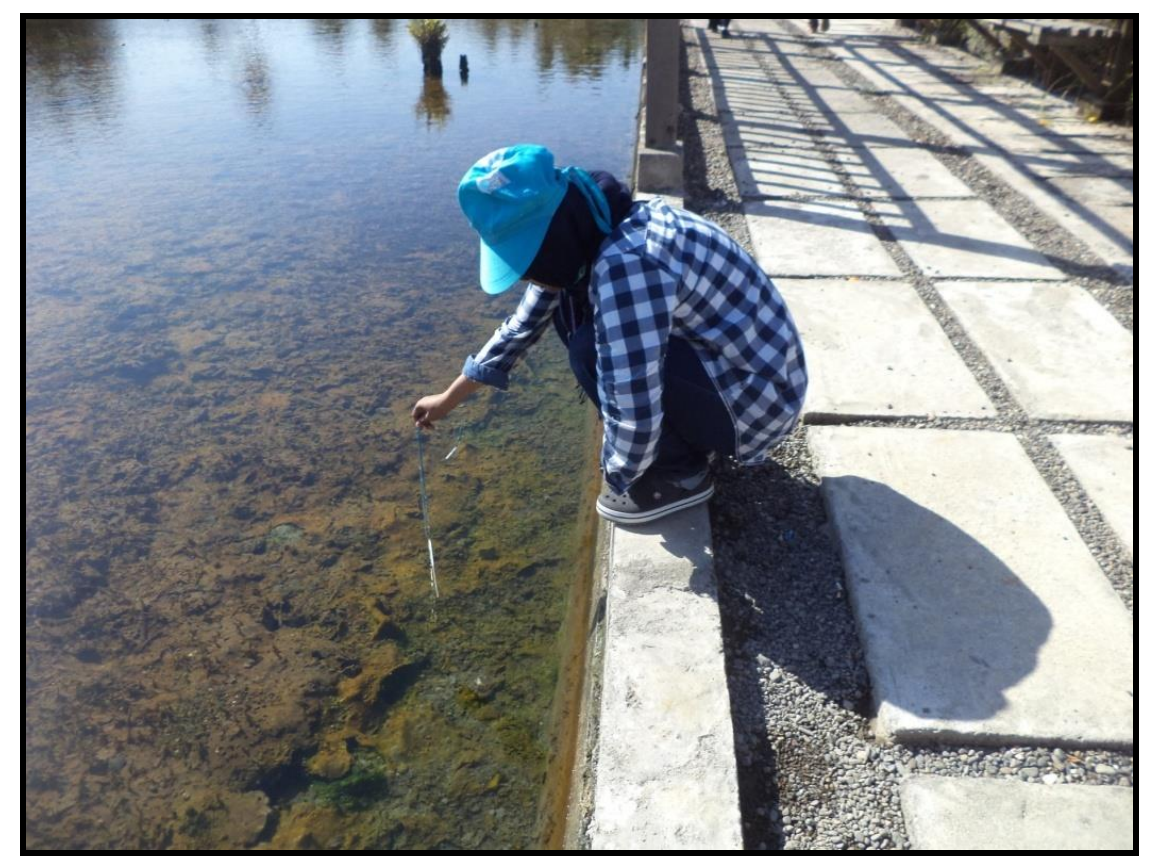

Gambar 2. Pengukuran Suhu Menggunakan Termometer pada Stasiun 1, dengan suhu $45^{\circ} \mathrm{C}$ dan difoto ke Arah Barat Laut $\left(\mathrm{N} 315^{\circ} \mathrm{E}\right)$ 
Pengamatan, pengukuran dan pengambilan data pada stasiun 1 dilakukan di dalam lokasi pemandian Sulili dengan elevasi 25 meter. Kenampakan fisik mata air panas pada stasiun 1 memiliki warna yang bening, berbau Sulfur, rasanya payau, temperatur air $45^{\circ} \mathrm{C}$ dengan suhu udara sekitar $32^{\circ} \mathrm{C}$. Memiliki pH 7 dan airnya tidak keruh. Mata air panas pada stasiun 1 berada dalam kolam yang berukuran 30 meter $\times 20$ meter. Dapat dilihat pada gambar 2. Berdasarkan pengamatan dan wawancara dengan pengelola air panas Sulili, saat ini Kawasan Pemandian Sulili dijadikan sebagai tempat rekreasi, kegiatan PORDA (Pekan Olahraga Daerah) dan lokasi penelitian dari berbagai disiplin ilmu.

\section{Mata air panas Stasiun 2 (ST-2)}

Pengamatan, pengukuran dan pengambilan data pada stasiun 2 dilakukan di dalam lokasi Pemandian Sulili. Terletak pada zona UTM 08001399583300 dengan elevasi 30 meter (Gambar 3).

Kenampakan fisik mata air panas pada stasiun 2 memiliki warna yang bening, berbau Sulfur, rasanya payau dengan temperatur air $57^{\circ} \mathrm{C}$ dengan suhu udara sekitar $32^{\circ} \mathrm{C}$. Nilai pH dari mata air panas adalah 7 dan airnya tidak keruh. Mata air panas ini teridentifikasi sebagai sumber mata air dengan arah penyebaran air $\mathrm{N} 135^{\circ} \mathrm{E}$ dan mengeluarkan uap yang terus menerus. Mata air panas ini juga memiliki air yang tenang dan tidak memiliki arus.

\section{Mata air panas Stasiun 3 (ST-3)}

Pengamatan, pengukuran dan pengambilan data pada stasiun 3 dilakukan di depan rumah penduduk, berupa kolam dengan panjang 4 meter, lebar 2 meter dan kedalaman 0,5 meter. Terletak pada zona UTM 0800145-9583362 dengan elevasi 30 meter. Mata air panas ini juga memperlihatkan adanya pemunculan gelembung-gelembung air (bergolak) yang keluar terus-menerus dengan sebaran setempat-tempat dalam kolam penduduk tersebut. Kenampakan fisik mataair panas pada stasiun 3 memiliki warna bening berbau sulfur dengan rasa payau, suhunya mencapai $49^{\circ} \mathrm{C}$ dengan suhu udara sekitar $32^{\circ} \mathrm{C}$, memiliki $\mathrm{pH} 7$ dan airnya tidak keruh (Gambar 4).

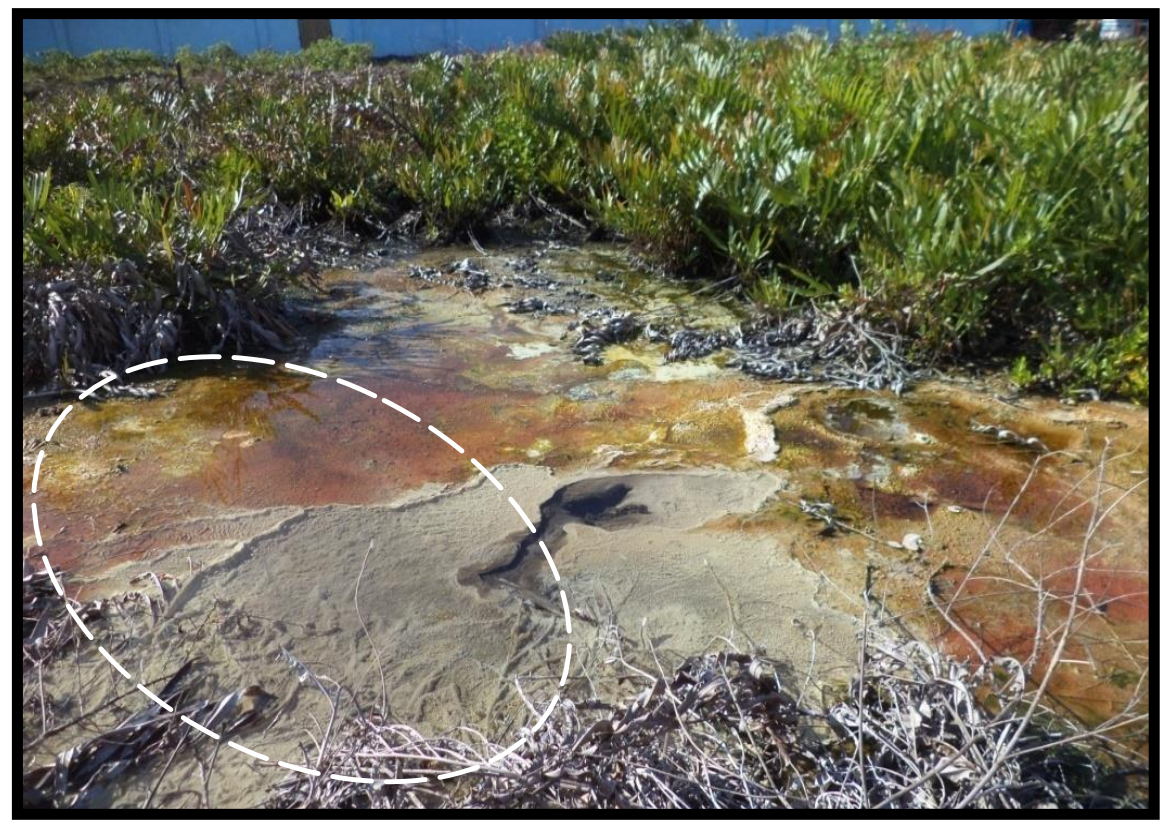

Gambar 3. Pengamatan Arah Penyebaran Mata Air Panas $135^{\circ} \mathrm{E}$ pada Stasiun 2, Difoto ke Arah Timur-Timur Laut (N $\left.65^{\circ} \mathrm{E}\right)$ 


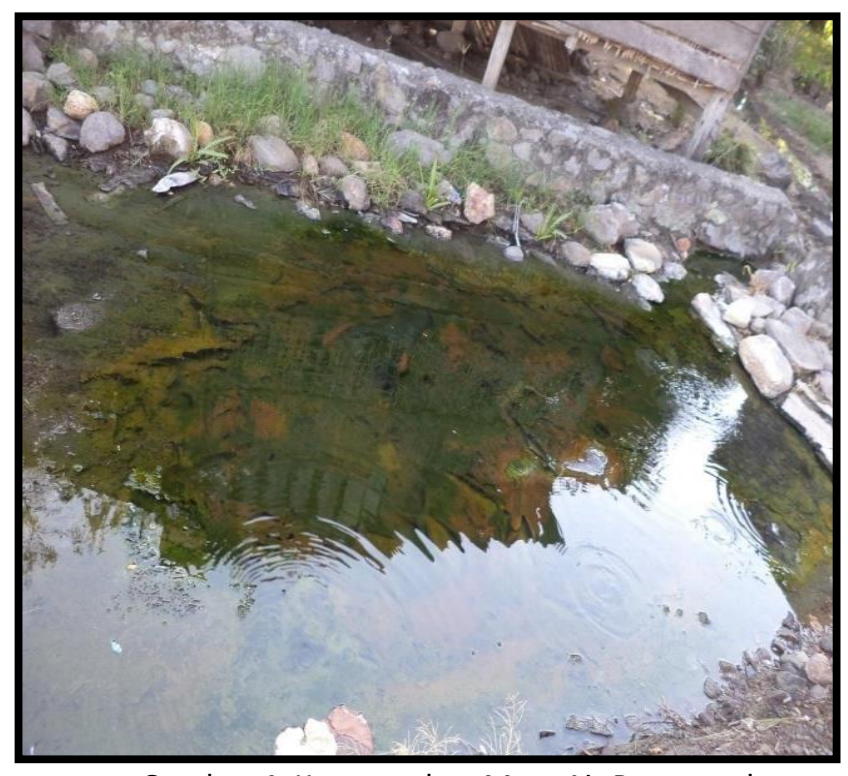

Gambar 4. Kenampakan Mata Air Panas pada

Stasiun 3 yang berwarna bening dan berasa payau serta berasa sulfur, difoto ke Arah Timur ( $\mathrm{N} \mathrm{90^{ \circ } \mathrm { E } )}$

Tabel 1. Sifat Fisik Mata Air Panas Daerah Penelitian (Sumber: Data Lapangan)

\begin{tabular}{cccc}
\hline & \multicolumn{3}{c}{ Mata Air Panas } \\
\cline { 2 - 4 } & ST-1 & ST-2 & ST-3 \\
Warna & Bening & Bening & Bening \\
Bau & Sulfur & Sulfur & Sulfur \\
$\begin{array}{c}\text { Rasa } \\
\left.\text { Suhu ( }{ }^{\circ} \mathrm{C}\right)\end{array}$ & Payau & Payau & Payau \\
Lakmus) & $45^{\circ} \mathrm{C}$ & $57^{\circ} \mathrm{C}$ & $49{ }^{\circ} \mathrm{C}$ \\
\hline
\end{tabular}

Proses pengamatan, pengukuran dan pengambilan data di lokasi penelitian dengan parameter yang terdiri dari warna, bau, rasa, temperatur dan $\mathrm{pH}$ ditunjukkan pada Tabel 1, kemudian sampel air dianalisis di laboratorium dan menunjukkan hasil data yang disajikan pada Tabel 2.

Hasil pemeriksaan sampel yang dianalisis di Laboratorium terdiri dari analisis warna, $\mathrm{pH}, \mathrm{DHL}$ (Daya Hantar Listrik), TDS (Total Dissolved Solid) dan kekeruhan. Adapun hasil analisis laboratorium data sifat fisik mata air panas di Daerah Sulili Kecamatan
Paleteang Kabupaten Pinrang Provinsi Sulawesi Selatan, ditunjukkan pada Tabel 2.

Tabel 2. Data Hasil Pemeriksaan Sampel Air di Laboratorium (Sumber: Laboratorium Oseanografi Kimia di Fakultas IImu Kelautan dan Perikanan Universitas Hasanuddin Makassar)

\begin{tabular}{ccccc}
\hline \multirow{2}{*}{ Parameter Uji } & & \multicolumn{3}{c}{ Mata Air Panas } \\
\cline { 3 - 5 } & Satuan & ST-1 & ST-2 & ST-3 \\
\hline pH Digital & - & 7,83 & 7,99 & 7,9 \\
Kekeruhan & NTU & 1,54 & 0,95 & 6,04 \\
Warna & TCU & 17 & 23 & 4 \\
DHL & $\mathrm{mS} / \mathrm{cm}$ & 4,35 & 4,23 & 4,52 \\
TDS & $\mathrm{g} / \mathrm{L}$ & 2,13 & 1,85 & 2,12 \\
$\begin{array}{c}\text { H S sebagai } \\
\text { Sulfida }\end{array}$ & $\mathrm{mg} / \mathrm{L}$ & 4,913 & 2,215 & 1,183 \\
\hline
\end{tabular}

Grafik hasil analisis Laboratorium berupa data sifat fisik mata air panas di Daerah Sulili Kecamatan Paleteang Kabupaten Pinrang Provinsi Sulawesi Selatan, menunjukkan perbedaan hasil tiap stasiun yang dapat dilihat pada gambar 5 .

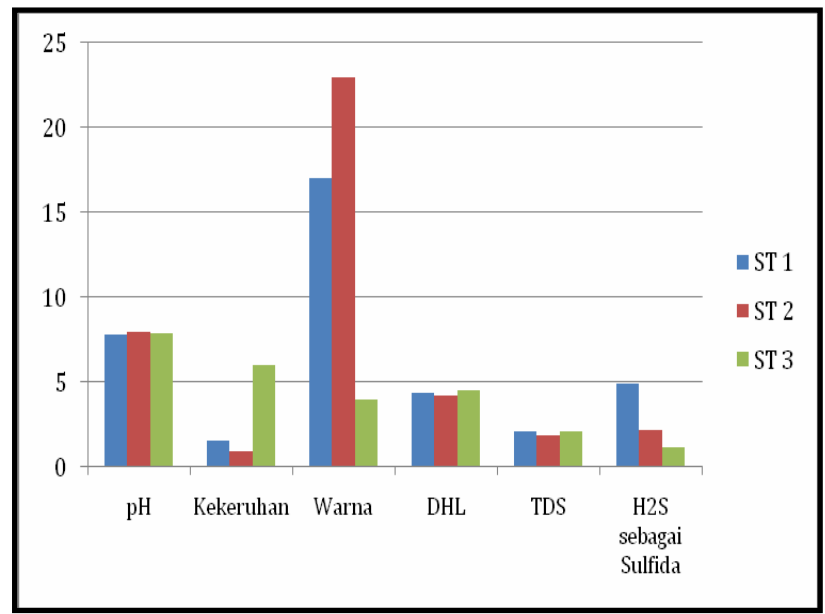

Gambar 5. Grafik Hasil Analisis di Laboratorium

Gambar 5 merupakan grafik hasil analisis di Laboratorium dengan parameter $\mathrm{pH}$, kekeruhan, warna, DHL (Daya Hantar Listrik), TDS (Total Dissolved Solid) dan $\mathrm{H}_{2} \mathrm{~S}$ sebagai Sulfida, terdiri dari 3 (tiga) stasiun yang memiliki nilai berbeda-beda, stasiun 1 ditandai dengan warna biru, stasiun 2 dengan warna merah dan stasiun 3 berwarna hijau. 
Berikut uraian parameter yang merupakan hasil analisis di Laboratorium pada ketiga stasiun pengambilan sampel:

1. Warna

Berdasarkan hasil pengamatan di lokasi penelitian mata air panas Daerah Sulili berwarna jernih. Kenampakan warna fisik mata air panas yang berwarna bening, tidak terlepas dari adanya material-material batuan tufa yang menyusun satuan alluvial (Umar dan Nawir, 2018). Batuan tufa ini memiliki porositas maupun permeabilitas yang baik dalam menyimpan dan meloloskan air termasuk dalam menyaring unsur hara atau material kotor ke dalam pori-pori tanah sehingga dapat mempengaruhi warna air dengan warna mata air panas berwarna bening (Umar dkk., 2019).

Hal demikian diperkuat dengan hasil analisis laboratorium yang diperoleh pada stasiun 1 yaitu 17 TCU, stasiun 2 dengan 23 TCU dan stasiun 3 yaitu 4 TCU (Tabel 2) sedangkan standar kualitas air bersih yaitu maksimal 50 TCU sehingga dari segi warna ketiga stasiun tersebut memenuhi standar untuk syarat kualitas air bersih.

\section{Bau}

Mata air panas mengandung sulfat akibat oksidasi gas $\mathrm{H}_{2} \mathrm{~S}$ di dekat permukaan membentuk larutan $\mathrm{H}_{2} \mathrm{SO}_{4}$ (Herdianita, 2007). Hasil analisis di Laboratorium menunjukkan adanya kandungan belerang yaitu pada stasiun 1 yaitu 4,913 mg/L, stasiun 2 yaitu $2,215 \mathrm{mg} / \mathrm{L}$ dan stasiun 3 yaitu 1,183 $\mathrm{mg} / \mathrm{L}$ (Tabel 2).

Berdasarkan hasil pengamatan di lapangan diindikasikan mata air panas di daerah penelitian berbau belerang namun kandungan dari belerang tersebut terlampau kecil. Mata air panas di Daerah Sulili berbau belerang karena adanya kandungan gas $\mathrm{H}_{2} \mathrm{~S}$ (Tabel 2).

\section{Rasa}

Berdasarkan hasil penyelidikan di lapangan mata air panas pada daerah penelitian berasa payau. Hasil analisis di Laboratorium juga menunjukkan hasil yang sama pada mata air panas yaitu memiliki rasa payau dari hasil TDS (Total Dissolved Solid) ketiga stasiun pengambilan sampel (Tabel 2).

\section{Suhu}

Hasil pengukuran di lapangan yang dilakukan pada pukul 15:10 WITA. Setiap stasiun diukur menggunakan termometer menunjukkan angka yang berbeda yaitu di stasiun 1 dengan suhu $45^{\circ} \mathrm{C}$, stasiun 2 yaitu $57^{\circ} \mathrm{C}$ dan stasiun 3 adalah $49^{\circ} \mathrm{C}$ dengan suhu udara sekitar di setiap stasiun pada angka $32^{\circ} \mathrm{C}$.

Semakin tinggi suhu maka reaksi kimia akan semakin cepat sedangkan konsentrasi gas akan semakin menurun, termasuk kadar oksigen di dalam air (Letterman dkk., 1999). Suhu pada suatu ekosistem air dipengaruhi oleh berbagai faktor seperti intensitas cahaya matahari, pertukaran panas antara air dengan udara sekelilingnya dan ketinggian geografis.

Hasil pengukuran temperatur permukaan dari ketiga mata air panas berbeda- beda, suhu permukaan mata air panas Daerah Sulili berkisar dari $45^{\circ} \mathrm{C}-57^{\circ} \mathrm{C}$ sehingga pada daerah penelitian termasuk dalam low temperature water (Iswahyudi et al., 2019) yang merupakan penciri dari mata air panas akibat proses tektonik aktif (Jamaluddin dan Umar, 2017); (Umar dkk., 2020)).

\section{5. $\mathrm{pH}$}

Berdasarkan hasil pengukuran di lapangan mata air panas menggunakan indikator pH (kertas lakmus) yaitu relatif sama dengan $\mathrm{pH} 7$ atau netral.

Hasil analisis Laboratorium diperoleh bahwa pada mata air di stasiun 1 yaitu 7,83, stasiun 2 yaitu 7,99 dan stasiun 3 yaitu 7,9 (Tabel 2) dengan sifat air netral-basa. Sifat asam dan basa suatu mata air ditentukan oleh sifat batuan reservoir, berbeda jenis batuan maka berbeda pula sifat keasaman mata air panasnya (Asdak, 2018). Di daerah penelitian tergolong air yang bersifat netral-basa.

\section{Kekeruhan}

Berdasarkan hasil pengamatan di lapangan, mata air panas tersebut jernih dan relatif tenang ditunjang dengan hasil analisis di laboratorium, 
sampel air yang diambil pada stasiun 1 diperoleh hasil yaitu 1,54 NTU, stasiun 2 yaitu 0,95 NTU dan stasiun 3 yaitu 6,04 NTU (Tabel 2). Standar kekeruhan maksimun yaitu 5 NTU. Namun, pada stasiun 3 diperoleh nilai kekeruhan yaitu 6,04 NTU sehingga tidak memenuhi syarat untuk kualitas air bersih.

Kekeruhan air disebabkan oleh partikel-partikel yang tersuspensi di dalam air dan menyebabkan air terlihat keruh, kotor, bahkan berlumpur. Bahanbahan yang menyebabkan air keruh antara lain tanah liat, pasir dan lumpur (Muliani, 2016)). Di daerah penelitian, mata air panas yang berada di depan rumah warga (ST-3) kurang terawat karena banyaknya kotoran berupa sampah dedaunan (Gambar 4) dari pepohonan yang berada di sekitar lokasi munculnya mata air panas.

\section{Total Padatan Terlarut (Total Dissolved} Solid,TDS)

Air bersih atau fresh water memiliki nilai TDS terukur 100-500 mg/L. Sementara itu, hasil pengukuran nilai TDS pada mata air panas Daerah Sulili di stasiun 1 yaitu 2,13 g/L (Tabel 2) jika dikonversi sebesar $2.130 \mathrm{mg} / \mathrm{L}$, termasuk dalam klasifikasi air payau (brackish water). Stasiun 2 yaitu $1,85 \mathrm{~g} / \mathrm{L}$ jika dikonversi sebesar $1.850 \mathrm{mg} / \mathrm{L}$ termasuk dalam klasifikasi air sadah non-karbonat (non carbonat hardness water) dan stasiun 3 yaitu 2,12 g/L jika dikonversi sebesar 2.120 mg/L termasuk dalam klasifikasi air payau (brackish water). Oleh karena itu, ketiga stasiun tidak sesuai dengan klasifikasi air bersih berdasarkan jumlah padatan terlarut (Leonore et al., 1998 dalam Mukarromah, 2016).

\section{Daya Hantar Listrik (DHL)}

Hasil pengukuran nilai DHL pada mata air panas Daerah Sulili pada stasiun 1 yaitu $4,35 \mathrm{mS} / \mathrm{cm}$, stasiun 2 adalah $4,23 \mathrm{mS} / \mathrm{cm}$ dan stasiun 3 yakni $4,52 \mathrm{~ms} / \mathrm{cm}$ (Tabel 2) jika dikonversi akan mendapatkan hasil $4.350 \mu \mathrm{mhos} / \mathrm{cm}$ untuk stasiun 1. Stasiun 2 dan 3 yaitu $4.230 \mu \mathrm{mhos} / \mathrm{cm}$ dan 4.520 $\mu \mathrm{mhos} / \mathrm{cm}$. Maka dari itu, nilai DHL dengan nilai tersebut berada jauh di atas ambang batas kadar maksimum DHL pada kualitas air bersih. Kadar maksimun ambang batas DHL yang diperbolehkan untuk air bersih adalah $2.250 \mu$ mhos/.

Nilai DHL dipengaruhi oleh kandungan ion anorganik (TDS) dalam air. Sementara itu, pengukuran nilai DHL untuk identifikasi kualitas air menggunakan dua analogi yaitu semakin murni air maka nilai DHL akan semakin kecil dan semakin murni air maka kualitas air akan semakin baik (Mukarromah dkk., 2016). Semakin tinggi konduktivitas dalam air maka air akan terasa payau sampai asin (Mahida, 1986 dalam (Mukarromah dkk., 2016)).

\section{Kondisi Fluida Panas Bumi Daerah Penelitian}

Hasil pengamatan, pengukuran dan pengambilan data pada mata air panas di Daerah Sulili Kecamatan Paleteang Kabupaten Pinrang Provinsi Sulawesi Selatan menurut analisis fisik rata-rata nilai $\mathrm{pH}$ tergolong netral sehingga mata air panas yang bersifat netral biasanya merupakan manifestasi permukaan dari suatu sistem panas bumi yang didominasi oleh air ((Umar dkk., 2013);(Saptadji, 2018)).

Munculnya mata air panas di daerah penelitian dengan suhu udara yaitu $32^{\circ} \mathrm{C}$ dan suhu mata air antara $45^{\circ} \mathrm{C}-57^{\circ} \mathrm{C}$ disebabkan oleh proses tektonik aktif (Umar et al., 2020) yang dicirikan oleh air panas temperatur permukaan rendah (low temperatur water) (Iswahyudi dkk., 2019) dengan suhu antara $20^{\circ}-100^{\circ} \mathrm{C}$.

\section{Pemanfaatan Mata Air Panas Daerah Penelitian}

Berdasarkan pengamatan, analisis data, wawancara dengan staf Dinas Pariwisata yang bertugas serta masyarakat sekitar tempat wisata mata air panas Daerah Sulili dan merujuk pada Peraturan Gubernur Sulawesi Selatan Nomor:69 Tahun 2010 Tentang Baku Mutu dan Kriteria Kerusakan Lingkungan Hidup maka mata air panas Daerah Sulili dapat dimanfaatkan sebagai berikut:

\section{Kualitas Air}

Hasil analisis komparatif tentang sifat fisik mata air panas pada stasiun 1, 2, dan 3 diperoleh lima parameter yang tidak memenuhi syarat kualitas air 
bersih. Parameter yang tidak memenuhi syarat kualitas air bersih yaitu dari segi bau, DHL, TDS, temperatur dan kekeruhan. Dari 3 sampel yang diambil dari lokasi penelitian kemudian dilakukan pemeriksaan di Laboratorium menunjukkan hasil yang sama yaitu memiliki rasa payau dari hasil pemeriksaan TDS (Total Dissolved Solid) yaitu 2030 $\mathrm{mg} / \mathrm{L}$ yang masuk dalam klasifikasi air sadah nonkarbonat sehingga tidak layak untuk dimanfaatkan sebagai air minum. Dari segi kekeruhan di mata air stasiun 3 diperoleh nilai kekeruhan yaitu 6,04 NTU sehingga tidak memenuhi syarat untuk kualitas air bersih. Namun, dua stasiun lainnya (ST-1dan ST-2) termasuk ke dalam kategori layak digunakan sebagai air bersih.

\section{Tempat Pariwisata}

Sumber panas bumi dengan temperatur rendah $\left(<125^{\circ} \mathrm{C}\right)$ dapat langsung digunakan sebagai pemanas soil dan rumah kaca dalam kegiatan bercocok tanam di daerah dingin atau dapat juga digunakan sebagai pemandian air panas di Daerah Objek Wisata (Saptadji, 2018).

\section{Kesehatan}

Mata air panas dapat mengencerkan padatan mineral sehingga air yang berasal dari mata air panas tersebut mengandung kadar mineral yang tinggi. Kandungan mineral pada mata air panas seperti air sulfur meningkatkan proliferasi limfosit dalam darah pasien. Air yang kaya sulfur juga sangat membantu masalah respirasi atau pernafasan. Sumber air mineral dapat merilekskan kejang otot pada saluran bronkial. Membantu meregulasi sifat otot pada saluran respirasi dan merupakan antiseptik (Moore dkk., 2009).

Menurut (Sukenik dkk., 1999) mandi di laut mati atau kolam air yang penuh dengan sulfur atau kombinasi keduanya sangat menguntungkan untuk pasien osteoartritis.

Mata air panas pada Daerah Sulili Kecamatan Paleteang Kabupaten Pinrang Provinsi Sulawesi Selatan mengandung belerang $\left(\mathrm{H}_{2} \mathrm{~S}\right.$ sebagai Sulfida) dan air hangat yang baik untuk kesehatan. Suhu air saat mandi tidak lebih tinggi dari $44^{\circ} \mathrm{C}$ selama $5-10$ menit akan memberikan manfaat kesehatan bagi tubuh manusia.

\section{Pusat Studi Terpadu}

Mata air panas daerah penelitian dapat dimanfaatkan sebagai pusat penelitian terpadu seperti pada bidang geologi, panas bumi, hidrologi, geofisika, geowisata dan ilmu kesehatan. Pada bidang geologi mengkaji mengenai sesar yang terjadi akibat tektonik lempeng yang terbentuk di daerah penelitian. Bidang panas bumi menganalisis tentang indikasi-indikasi kemunculan mata air panas.

Bidang hidrologi mengenai debit mata air panas yang keluar secara alamiah sehingga dapat diketahui potensi dari sumber daya akuifernya. Bidang geofisika mengenai gambaran bawah permukaan bumi seperti struktur sesar yang bertindak sebagai jalur keluarnya fluida panas bumi dan batuan terobosan yang bertindak sebagai sumber panas terutama keberadaan dari reservoir panas bumi guna pemanfaatan panas bumi. Keberadaan dari reservoir panasbumi guna menjadi rekomendasi pemanfaatan secara tidak langsung (indirect use) sebagai Pembangkit Listrik Tenaga Panasbumi (PLTP).

Bidang geowisata mengenai perencanaan dan pemanfaatan mata air panas untuk memenuhi kesejahteraan hidup masyarakat sekitar dan pada bidang ilmu kesehatan mengenai kandungankandungan kimia yang terdapat dalam mata air panas dan tingkat suhu yang berguna untuk kesehatan.

\section{PENUTUP}

\section{Simpulan}

1. Sifat fisik mata air panas pada permukaan yaitu memiliki suhu $45^{\circ} \mathrm{C}-57^{\circ} \mathrm{C}$ dengan $\mathrm{pH}$ yaitu 7,83 7,99 . Warna yang jernih dengan hasil analisis yaitu 4-23 TCU, berbau belerang dan memiliki rasa yang payau. Tingkat kekeruhan yaitu 0,956,04 NTU dengan kenampakan di lapangan yang jernih. Nilai pada DHL yaitu 4,23-4,52 $\mathrm{mS} / \mathrm{cm}$ dan TDS (Total Dissolved Solid) yaitu 1,85-2,13 $\mathrm{g} / \mathrm{L}$. 
2. Berdasarkan nilai $\mathrm{pH}$ rata-rata dari mata air panas termasuk $\mathrm{pH}$ netral maka sistem panas bumi daerah penelitian disebabkan oleh tektonik aktif dengan penciri daerah mata air panas yaitu low temperature water yang didominasi oleh air.

3. Manfaat dari mata air panas pada daerah penelitian yaitu dalam bidang pariwisata sebagai tempat pemandian air panas, bidang kesehatan dan sebagai pusat studi terpadu.

\section{Saran}

1. Bagi peneliti selanjutnya baiknya meneliti data kualitas sifat fisik material solid yang berasosiasi dengan mata air panas pada daerah penelitian, melakukan penelitian tentang reservoir panasbumi dengan menggunakan metode geofisika dan geokimia.

2. Baiknya dilakukan penelitian mengenai potensi belerang yang terkandung di dalam mata air panas pada daerah penelitian.

3. Bagi Pemerintah baiknya mengubah perlakuan pada kolam mata air panas, agar tidak dibeton karena dapat menyebabkan tekanan yang berada di permukaan lebih tinggi dibandingkan tekanan yang akan keluar dari dalam bumi sehingga akan merusak kealamian sumber mata air panas dan mempengaruhi lifetime mata air panasnya. Selain itu, mengimbau masyarakat sekitar untuk tetap menjaga kebersihan dengan tidak membuang sampah di lokasi munculnya mata air panas agar tetap terjaga kejernihan airnya.

\section{Ucapan Terima Kasih}

Terimakasih kepada Pemerintah Kabupaten Pinrang Sulawesi-Selatan, terkhusus Pemeritah setempat di Daerah Sulili begitupun Lembaga Penelitian dan Pengembangan Sumberdaya Yayasan Wakaf Universitas Muslim Indonesia Makassar (LP2S-UMI) atas segala bentuk dukungannya selama proses pelaksanaan penelitian hingga ke tahap publikasi.

\section{DAFTAR PUSTAKA}

Asdak, C. (2018), Hidrologi dan pengelolaan daerah aliran sungai, Gadjah Mada University Press.

Herdianita, N.R. (2007), LAPORAN PENELITIAN PROGRAM RISET KK - ITB 2007 MANIFESTASI PANASBUMI PERMUKAAN DI DAERAH CIDANAU DAN SEKITARNYA, ANYER - PROVINSI BANTEN, ITB, Bandung. Diambil dari https://fdokumen.com/document/44860934laporan-anyer2.html.

Iswahyudi, S., Attabik, L.W., Setijadi, R. dan Raharjo, S.A. (2019), "Perhitungan Temperatur Reservoir Panas Bumi Mata Air Panas Daerah Bantarkawung Menggunakan Metode Geotermometer Na-K Dan Entalpi-Silika", Jurnal Geosaintek, Vol.5, No.1, hal. 7-12-12. http://doi.org/10.12962/j25023659.v5i1.5055.

Jamaluddin, J. dan Umar, E.P. (2017), "KARAKTERISTIK FISIK DAN KIMIA MATAAIR PANAS DAERAH BARASANGA KABUPATEN KONAWE UTARA, PROVINSI SULAWESI TENGGARA", JURNAL GEOCELEBES, Vol.1, No.2, hal. 62-65. http://doi.org/10.20956/geocelebes.v1i2.2291.

Letterman, R.D., Association), A. (American W.W., Association, A.W.W. dan Staff, A.W.R.A. (1999), Google-Books-ID: yRxSAAAAMAAJ, Water Quality \& Treatment Handbook, McGraw-Hill Companies, Incorporated.

Moore, L., Acupuncturist, L., ND, MSOM dan L.Ac (2009), Healing with Mineral Water. Diambil 29 Desember 2020, dari https://www.fostercottage.org/content/museu $\mathrm{m} /$ Healing-Water.

Mukarromah, R., Yulianti, I. dan Sunarno, S. (2016), "ANALISIS SIFAT FISIS KUALITAS AIR DI MATA AIR SUMBER ASEM DUSUN KALIJERUK, DESA SIWURAN, KECAMATAN GARUNG, KABUPATEN WONOSOBO", Unnes Physics Journal, Vol.5, No.1, hal. 40-45.

Muliani, H. (2016), Analisis Kualitas Air Wisata Alam Pemandian Gumanano di Desa Gumanano Kecamatan Mawasangka Kabupaten Buton Tengah, Fakultas Keguruan dan Ilmu Pendidikan Universitas Halu Oleo Kendari, Kendari.

Saptadji, N.M. (2018), Google-Books-ID: iDV0yAEACAAJ, Prosiding Pertemuan IImiah Tahunan ke-2 Perhimpunan Ahli Airtanah Indonesia (PITPAAl), ITB Press, Bandung.

Sukenik, S., Flusser, D. dan Abu-Shakra, M. (1999), "The Role of Spa Therapy in Various Rheumatic Diseases", Rheumatic Diseases Clinics of North America, Vol.25, No.4, hal. 883-897. http://doi.org/10.1016/s0889-857x(05)701083.

Tutu, R., Subaer, S. dan Usman, U. (2015), "STUDI ANALISIS KARAKTERISASI DAN MIKROSTRUKTUR MINERAL SEDIMEN SUMBER AIR PANAS SULILI 
DI KABUPATEN PINRANG", Jurnal Sains dan Pendidikan Fisika, Vol.11, No.2, hal. 192-201. http://doi.org/10.35580/jspf.v11i2.1488.

Umar, E.P., Anwar, H., Husain, J.R. dan Muharni, S. (2020), "PENGARUH STRUKTUR GEOLOGI TERHADAP KEMUNCULAN MATAAIR PANAS DAERAH SULILI PINRANG SULAWESI SELATAN", JURNAL GEOCELEBES, Vol.4, No.1, hal. 41-45. http://doi.org/10.20956/geocelebes.v4i1.9542.

Umar, E.P. dan Jamaluddin, J. (2018), "KARAKTERISTIK ENDAPAN SINTER TRAVERTIN PANAS BUMI BARASANGA KABUPATEN KONAWE UTARA, SULAWESI TENGGARA", JURNAL GEOCELEBES, Vol.2, No.2, hal. 64-69. http://doi.org/10.20956/geocelebes.v2i2.4830.

Umar, E.P. dan Nawir, A. (2018), "POTENSI AIRTANAH DANGKAL DALAM PEMENUHAN KEBUTUHAN AIR BERSIH KOTA MAKASSAR", Jurnal Geomine, Vol.6, No.2. http://doi.org/10.33536/jg.v6i2.215.

Umar, E.P., Nawir, A., Jamaluddin, J. dan Nurfalaq, A. (2019), "PENGARUH KONDISI GEOLOGI LINGKUNGAN TERHADAP POTENSI AIR TANAH DALAM DI KOTA MAKASSAR", JURNAL GEOCELEBES, Vol.3, No.1, hal. 13-18. http://doi.org/10.20956/geocelebes.v3i1.6150.

Umar, E.P., Tonggiroh, A. dan Irfan, U.R. (2013), ANALISIS BAWAH PERMUKAAN DAERAH MANIFESTASI PANASBUMI BARASANGA MENGGUNAKAN METODE RESISTIVITAS KABUPATEN KONAWE UTARA, SULAWESI TENGGARA I PERPUSTAKAAN UNIVERSITAS HASANUDDIN, Jurusan Geologi, Fakultas Teknik, Universitas Hasanudin, Makasar. Diambil dari http://digilib.unhas.ac.id/opac/detailopac?id=10158.

Winarsih, F.P. (2014), IDENTIFIKASI LITOLOGI DAERAH MANIFESTASI PANAS BUMI PARANGWEDANG KABUPATEN BANTUL DIY DENGAN METODE MAGNETIK, skripsi, UNIVERSITAS ISLAM NEGERI SUNAN KALIJAGA. Diambil dari http://digilib.uin-suka.ac.id/14729/. 